\title{
PENGARUH MODEL PEMBELAJARAN OPEN ENDED BERBASIS KETERAMPILAN MENJELASKAN TERHADAP KOMPETENSI PENGETAHUAN IPA
}

\author{
Kadek Dita Lestari, Ni Wyn. Suniasih, I.B Surya Manuaba \\ Program Studi Pendidikan Guru Sekolah Dasar, Universitas Pendidikan Ganesha \\ E-mail :ditakadek06@gmail.com,niwayan.suniasih@undiksha.ac.id, manuabasurya@yahoo.com
}

\begin{abstract}
Abstrak
Tujuan penelitian ini adalah untuk mengetahui pengaruh model pembelajaran open ended berbasis keterampilan menjelaskan terhadap kompetensi pengetahuan IPA pada siswa kelas V SD Gugus IV Jendral Sudirman Denpasar Selatan Tahun Ajaran 2016/2017. Jenis penelitian ini merupakan eksperimen semu dengan desain penelitian rancangan kelompok non-ekiuvalen. Populasi penelitian ini adalah seluruh siswa kelas V SD Gugus IV Jendral Sudirman Denpasar Selatan tahun ajaran 2016/2017 yang jumlahnya 341 orang. Sampel ditentukan dengan teknik sampel kelompok dengan mengacak kelas. Penentuan kelompok eksperimen dan kontrol dilakukan dengan cara undian sehingga diperoleh kelas V SD Negeri 13 Sesetan sebagai kelompok eksperimen dan kelas VA SD Negeri 2 Sesetan sebagai kelompok kontrol dengan jumlah masing-masing kelompok sebanyak 39 orang. Data hasil kompetensi pengetahuan IPA dikumpulkan dengan instrumen berupa tes esai berjumlah 10 butir tes yang telah divalidasi. Data kompetensi pengetahuan IPA dianalisis dengan uji t. Hasil analisis menunjukkan bahwa terdapat perbedaan yang signifikan kompetensi pengetahuan IPA antara kelompok eksperimen dengan kelompok kontrol siswa kelas V SD Gugus IV Jendral Sudirman Denpasar Selatan tahun ajaran 2016/2017. Hal tersebut dibuktikan dengan hasil thitung $=3,497>\operatorname{tabel}(\alpha=0,05,76)=2,000$. Rerata kompetensi pengetahuan IPA kelompok eskperimen $\bar{X}=78,05>\bar{X}=71,51$ rerata kompetensi pengetahuan IPA kelompok kontrol. Dengan demikian dapat disimpulkan bahwa model pembelajaran open ended berbasis keterampilan menjelaskan berpengaruh terhadap kompetensi pengetahuan IPA pada siswa kelas V SD Gugus IV Jendral Sudirman Denpasar Selatan tahun ajaran $2016 / 2017$
\end{abstract}

Kata-kata kunci : open ended, keterampilan menjelaskan, IPA

\begin{abstract}
The purpose of this research is to know the effect of open ended skill-based learning model to the knowledge competence of science in grade V SD Gugus IV Jendral Sudirman South Denpasar Academic Year 2016/2017. This type of research is a pseudo experiment with non-ekiuvalent group design research design. The population of this study is all students of grade V SD Gugus IV Jendral Sudirman South Denpasar academic year 2016/2017 which number 341 students. The sample is determined by group sample technique by randomizing the class. The determination of the experimental and control group was done by drawing so as to obtain the grade V SD Negeri 13 Sesetan as the experimental group and the class of VA SD Negeri 2 Sesetan as the control group with the total of each group as many as 39 students. Data on knowledge competence knowledge of IPA was collected by instrument in the form of essay test amounting to 10 test items that have been validated. Knowledge competence data of IPA were analyzed by t test. The result of the analysis shows that there is a significant difference of science knowledge competence between the experimental group and the control group of students of grade V SD Gugus IV Jendral Sudirman South Denpasar academic year 2016/2017. This is evidenced by the result tcount $=3.479>$ ttable $(\alpha=0.05,76)=2,000$. Mean of knowledge competence of experimental group IPA $=78,05>=$ 71,51 knowledge science competency level of control group. Thus it can be concluded that the open-ended learning model based on skills explain the influence of knowledge competence of science in grade V SD Gugus IV Jendral Sudirman Denpasar Selatan academic year 2016/2017.
\end{abstract}

Keywords: open ended, explaining skill, IPA

\section{Pendahuluan}

Pendidikan merupakan hal pokok yang mutlak harus didapatkan oleh setiap orang. Menurut undangundang RI Nomor 20 Tahun 2003 mendefinisikan pendidikan sebagai usaha sadar dan terencana untuk mewujudkan suasana belajar dan proses pembelajaran sehingga peserta didik secara aktif mengembangkan potensi dirinya untuk memiliki kekuatan spiritual keagamaan, pengendalian diri, kepribadian, kecerdasan, akhlak mulia, serta keterampilan yang diperlukan dirinya, masyarakat, bangsa dan Negara.

Pendidikan dapat berlangsung dimana saja, seperti halnya pendidikan yang dilaksanakan di rumah (pendidikan informal) serta pendidikan yang dilaksanakan di sekolah (pendidikan formal). Pendidikan formal dilaksanakan oleh seorang tenaga pendidik yang memberikan pemahaman kepada peserta didik. Dalam pendidikan 
formal tentunya terjadi proses pembelajaran yang di dalamnya mencakup kegiatan belajar mengajar antara guru dan peserta didik.

Pembelajaran yang berlangsung di dalam pendidikan formal disesuaikan dengan kehidupan sehari-hari siswa, sehingga siswa dapat dengan mudah memahami materi yang disajikan guru karena siswa mengalami langsung permasalahan tersebut. Pembelajaran yang berlangsung saat ini sesuai dengan kurikulum 2013. Kurikulum 2013 adalah salah satu upaya pemerintah untuk memperbaiki kualitas mutu pendidikan. Kurikulum 2013 bertujuan untuk mempersiapkan manusia Indonesia agar memiliki kemampuan hidup sebagai pribadi dan warga negara yang beriman, produktif, kreatif, inovatif, dan afektif serta mampu berkontribusi pada kehidupan bermasyarakat, berbangsa, bernegara, dan peradaban dunia. Dalam pelaksanaannya, kurikulum 2013 ini menggunakan pendekatan saintifik. Untuk mewujudkan harapan dari kurikulum 2013 tentunya diperlukan pembelajaran yang dapat meningkatkan keingintahuan siswa untuk mengetahui sesuatu hal yang baru dan mengarahkan siswa pada proses pemecahan masalah.

Namun kenyataannya pembelajaran yang didapatkan siswa belumlah dapat meningkatkan keingintahuan siswa untuk mengetahui sesuatu hal yang baru. Berdasarkan hasil wawancara dengan kepala sekolah SD Gugus IV Jendral Sudirman Kecamatan Denpasar Selatan dalam proses pembelajaran terutama menyangkut bidang IPA masih banyak kelemahan dilihat dari hasil belajar IPA siswa, terutama kompetensi pengetahuan. Berdasarkan informasi yang didapatkan hal itu disebabkan karena selama proses pembelajaran, siswa yang mau bertanya dan menjawab pertanyaan guru maupun teman-teman hanya beberapa orang, akibatnya peran siswa dalam proses pembelajaran berkurang serta kemampuan guru dalam menjelaskan materi masih belum maksimal sehingga siswa sulit mengerti dengan apa yang dijelaskan oleh gurunya. Selama proses pembelajaran guru kurang mengarahkan cara berpikir siswa kepada pemecahan masalah. Banyak siswa yang beranggapan bahwa belajar tidak merupakan kebutuhan bagi dirinya.

Dalam permasalahan ini dipandang perlu untuk mencoba memadukan pendekatan saintifik dalam kurikulum 2013 dengan model pembelajaran yang berpusat pada siswa, berbasis masalah, terintegrasi, berbasis masyarakat, memberikan pilihan, tersistem, dan berkelanjutan. Maka dari itu pembelajaran yang diupayakan sesuai dengan kurikulum 2013 adalah dengan menerapkan model pembelajaran yang relevan. Salah satu model pembelajaran yang relevan dengan kurikulum 2013 adalah model pembelajaran open ended berbasis keterampilan menjelaskan.

Pembelajaran dengan problem (masalah) terbuka artinya pembelajaran yang menyajikan masalah dengan pemecahan berbagai cara (flexibility) dan solusinya juga bisa beragam (multi jawab, fluency), (Ngalimun, 2015:232). Pembelajaran ini melatih dan menumbuhkan orisinilitas ide, kreativitas, kognitif tinggi, kritis, komunikasi - interaksi, sharing, keterbukaan, dan sosialisasi. Siswa dituntut untuk berimprovisasi mengembangkan metode, cara, atau pendekatan yang bervariasi dalam memperoleh jawaban. Selanjutnya siswa juga diminta untuk menjelaskan proses pencapaian jawaban tersebut. Dengan demikian model pembelajaran ini lebih mementingkan proses daripada produk yang akan membentuk pola pikir, keterpaduan, keterbukaan dan ragam berpikir.

Pembelajaran ini melatih dan menumbuhkan orisinilitas ide, kreativitas, kognitif tinggi, kritis, komunikasi - interaksi, sharing, keterbukaan, dan sosialisasi. Siswa dituntut untuk berimprovisasi mengembangkan metode, cara, atau pendekatan yang bervariasi dalam memperoleh jawaban, jawaban siswa beragam. Selanjutnya siswa juga diminta untuk menjelaskan proses pencapaian jawaban tersebut. Dengan demikian model pembelajaran ini lebih mementingkan proses daripada produk yang akan membentuk pola pikir, keterpaduan, keterbukaan dan ragam berpikir.

Pembelajaran dengan model open-ended tidak hanya memberikan masalah-masalah terbuka kepada siswa untuk diselesaikan akan tetapi juga harus menjamin keterbukaan aktivitas siswa dalam proses pembelajarannya (Setiawan dan Harta, 2014:244). Taufik, (2014) menyatakan bahwa model open ended adalah model pembelajaran yang melibatkan siswa memecahkan masalah-masalah terbuka sebagai sarana untuk memperoleh pengetahuan yang baru, difokuskan pada aspek proses untuk menemukan strategi-strategi atau metode-metode untuk menemukan solusi-solusi dari masalah. Masalah yang menuntut pemahaman konsep siswa adalah masalah yang bersifat terbuka (open-ended). Jenis masalah ini dapat mengembangkan berbagai aspek kemampuan siswa. Pembelajaran dengan open-ended problem akan membuat kegiatan pembelajaran menjadi lebih bersifat student oriented. Siswa mendapat kesempatan untuk menginvestigasi berbagai strategi dan cara yang diyakininya. Ini akan membuat siswa mendapat kesempatan untuk mengekspresikan ide-idenya (Ariani, 2014:3). Model pembelajaran Open-Ended juga memberi kesempatan kepada siswa untuk memperoleh pengetahuan maupun pengalaman untuk menemukan, mengenali, dan memecahkan masalah tertutup ataupun terbuka dengan banyak cara sesuai dengan kemampuan yang telah dimiliki (Rahmawati, 2014:115).

Shoimin, (2014:112) menyatakan kelebihan model open ended yaitu (1) siswa berpartisipasi lebih aktif dalam pembelajaran dan sering mengekspresikan idenya; (2) siswa memiliki kesempatan lebih banyak dalam memanfaatkan pengetahuan dan keterampilan secara komprehensif; (3) siswa dengan kemampuan rendah dapat merespons permasalahan dengan cara mereka sendiri; (4) siswa secara intrinsik termotivasi untuk memberikan bukti 
atau penjelasan; serta (5) siswa memiliki pengalaman banyak untuk menemukan sesuatu dalam menjawab permasalahan.

Dalam penelitian ini model pembelajaran open ended akan dipadukan dengan keterampilan menjelaskan. Keterampilan menjelaskan merupakan penyajian informasi secara lisan yang diorganisasi secara sistematis untuk menunjukkan adanya hubungan yang satu dengan yang lainnya. Dengan perubahan kurikulum saat ini. Banyak guru yang beranggapan dalam Kurikulum 2013 tidak perlu menjelaskan materi tetapi banyak mata pelajaran yang masih memerlukan penjelasan guru. "Tidak semua peserta didik dapat menggali sendiri pengetahuan dari buku dan sumber lain, dan kurangnya sumber yang tersedia yang dapat dimanfaatkan oleh peserta didik" (Yanuar, 2015:43). Maka dari itu sangat perlu bagi seorang guru untuk memberikan penjelasan materi kepada peserta didik. Model pembelajaran open ended berbasis keterampilan menjelaskan merupakan sebuah model pembelajaran yang memberikan siswa kesempatan untuk memecahkan masalah dengan berbagai cara dan jawaban benar lebih dari satu disertai penjelasan guru yang dapat memudahkan siswa untuk memperoleh jawaban dari permasalahan yang didapatkan. Model pembelajaran open ended berbasis keterampilan menjelaskan ini dapat menumbuhkan keaktifan dan kreativitas siswa untuk menemukan solusi dalam pemecahan masalah yang diberikan oleh guru melalui penjelasan. Perpaduan model pembelajaran open ended dengan keterampilan menjelaskan akan terlihat dalam pembelajaran saat siswa mulai mengerjakan permasalahan yang didapatkan secara individu, kelompok sampai dengan menyimpulkan hasil diskusi. Pengetahuan yang didapatkan peserta didik tidak hanya sebatas hapalan semata tetapi pengetahuan yang bermakna, tidak cepat untuk dilupakan dan memberikan dampak yang positif terhadap hasil belajarnya. Kompetensi pengetahuan IPA adalah perubahan perilaku siswa yang mencerminkan kemampuan terhadap penguasaan materi IPA dari kemampuan berpikir meliputi mengingat, memahami/mengerti, menerapkan, menganalisis, mengevaluasi dan menciptakan. Dalam dimensi pengetahuan hanya pada pengetahuan faktual dan konseptual yang diukur menggunakan skor dari tes kompetensi pengetahuan setelah mengalami proses belajar, (Kosasih, 2014:21).

Adapun langkah-langkah yang harus ditempuh dalam penggunaan model pembelajarn open ended berbasis keterampilan menjelaskan yaitu (tahap 1) menyampaikan tujuan dan memotivasi siswa, (tahap 2) menyajikan informasi, (tahap 3) mengorganisasikan siswa ke dalam kelompok-kelompok belajar, (tahap 4) membimbing kelompok bekerja dan belajar, dan (tahap 5) evaluasi. Disetiap langkah memiliki penjelasannya masing-masing.

Berdasarkan uraian tersebut, model pembelajaran open ended berbasis keterampilan menjelaskan berpengaruh terhadap kompetensi pengetahuan IPA, tetapi secara empiris perlu dibuktikan melalui penelitian yang berjudul Pengaruh Model Pembelajaran Open Ended Berbasis Keterampilan Menjelaskan Terhadap Kompetensi Pengetahuan IPA pada Siswa Kelas V SD Gugus IV Jendral Sudirman Denpasar Selatan Tahun Ajaran 2016/2017.

Adapun tujuan dari penelitian ini yaitu untuk mengetahui pengaruh model pembelajaran open ended berbasis keterampilan menjelaskan terhadap kompetensi pengetahuan IPA pada siswa kelas V SD Gugus IV Jendral Sudirman Denpasar Selatan Tahun Ajaran 2016/2017

\section{Metode Penelitian}

Penelitian ini dilaksanakan pada semester 2 di kelas V SD Gugus IV Jenderal Sudirman Denpasar Selatan. Penelitian ini tergolong penelitian kuantitatif dengan rancangan eksperimen kuasi (Quasi-Eksperimental Design). rancangan eksperimen kuasi digunakan jika variabel-variabel luar yang mempengaruhi eksperimen tidak sepenuhnya bisa dikontrol serta pemilihan subjek penelitian tidak dapat dilakukan dengan cara pengacakan individu. Bentuk desain kuasi eksperimen yang digunakan adalah rancangan kelompok non-ekuivalen. Desain ini memberikan prates pada kelompok eksperimen dan kelompok kontrol, kemudian memberikan perlakuan pada kelas eksperimen berupa model pembelajaran open ended berbasis keterampilan menjelaskan. Setelah memberikan perlakuan, kelompok eksperimen dan kelompok kontrol diberikan pasca tes.

Dalam sebuah penelitian, pemilihan populasi merupakan hal yang sangat diperlukan. "Populasi adalah keseluruhan dari objek, orang, peristiwa atau sejenisnya yang menjadi perhatian dan kajian dalam penelitian"(Setyosari,2015:221). Sedangkan menurut Sugiyono (2016:61) "populasi adalah wilayah generalisasi yang terdiri dari obyek atau subyek yang menjadi kuantitas dan karakteristik tertentu yang ditetapkan oleh peneliti untuk dicari dan kemudian ditarik kesimpulannya". Jadi dapat disimpulkan bahwa populasi adalah keseluruhan dari objek individu yang memiliki karakteristik tertentu yang ingin diteliti oleh peneliti yang akan dipelajari dan ditarik kesimpulan. Populasi dari penelitian ini adalah seluruh siswa kelas V SD Gugus IV Jendral Sudirman Denpasar Selatan tahun ajaran 2016/2017 yang terdiri dari 8 kelas dalam 5 sekolah dasar yaitu SD Negeri 2 Sesetan, SD Negeri 6 Sesetan, SD Negeri 13 Sesetan, Sd Negeri 2 Serangan serta SD Negeri 3 Serangan. Jumlah populasi dari penelitian ini adalah 341 orang. Berdasarkan informasi yang diperoleh dari kepala sekolah serta guru kelas V di masing-masing SD Gugus IV Jendral Sudirman yaitu bahwa kelas V yang ada di SD Gugus IV Jendral Sudirman setara secara akademik yang memiliki nilai rata-rata tidak jauh berbeda. Dikatakan setara, karena pengelompokan siswa kedalam kelas-kelas yang ada disebar secara merata antara siswa yang memiliki kemampuan tinggi, sedang, dan rendah. Dengan demikian tidak terdapat kelas unggulan maupun non unggulan. 
Dalam melaksanakan penelitian, selain menentukan populasi, penentuan sampel merupakan hal yang sangat penting untuk mewakili populasi sebagai objek penelitian. "Sampel adalah sejumlah kelompok kecil yang mewakili populasi untuk dijadikan sebagai objek penelitian” (Setyosari, 2015:221). Sedangkan menurut Sugiyono (2016:62) menyatakan bahwa "sampel adalah bagian dari jumlah dan karakteristik yang dimiliki oleh populasi tersebut." Jadi dapat disimpulkan bahwa sampel adalah bagian dari populasi yang mewakili anggota populasi sebagai objek penelitian.

Teknik pengambilan sampel pada penelitian ini adalah sampel kelompok. Penentuan sampel penelitian ini tidak dilakukannya pengacakan individu melainkan hanya pengacakan kelas, karena tidak bisa mengubah kelas yang telah terbentuk sebelumnya. Cara yang digunakan adalah dengan cara pengundian. Cara undian dilakukan dengan menulis semua nama kelas $\mathrm{V}$ di seluruh SD populasi pada masing-masing kertas, kemudian kertas digulung. Ambil satu gulungan kertas, lalu ambil satu gulungan kertas lain, tanpa memasukkan kembali gulungan kertas pertama. Nama-nama SD pada kedua gulungan kertas tersebut merupakan sampel penelitian. Kedua kelas yang terpilih sebagai sampel tersebut diuji kesetaraanya secara empiris dengan menggunakan data nilai siswa setelah mengikuti prates.

Nilai prates yang diperoleh dari kedua kelompok dianalisis dengan teknik matching yang dilakukan dengan cara menjodohkan nilai prates siswa dari kedua kelompok. Darmadi (2014) menyatakan, teknik matching adalah suatu teknik untuk menyeragamkan kelompok pada suatu variabel atau lebih yang sudah diidentifikasi mempunyai hubungan yang erat dengan penampilan (performance) variabel tidak bebas.

Setelah mengadakan pengundian maka mendapat 2 kelas yakni kelas VA di SD Negeri 2 Sesetan dan kelas V di SD Negeri 13 Sesetan. Kelas VA di SD Negeri 2 Sesetan berjumlah 46 siswa dan kelas V di SD Negeri 13 Sesetan berjumlah 42 siswa. Nilai prates kedua kelompok siswa disetarakan menggunakan teknik matching dan mendapatkan hasil 39 siswa memiliki kemampuan yang setara secara akademik. Setelah diketahui kedua kelompok setara, maka dilakukan pengundian lagi dari 2 kelompok yang setara untuk memilih nama sekolah yang digunakan sebagai kelompok kontrol dan kelompok eksperimen. Berdasarkan hasil undian, diperoleh kelas V SD Negeri 13 Sesetan sebagai kelompok eksperimen serta Kelas VA SD Negeri 2 Sesetan sebagai kelompok kontrol.

Dalam sebuah penelitian eksperimen perlu dilakukan pengendalian terhadap validitas penelitian yang dapat mempengaruhi hasil penelitian. Dantes (2014:3) mengungkapkan "Validitas penelitian adalah kemampuan suatu penelitian untuk mengungkapkan secara tepat mengenai apa yang ingin diteliti”. Terdapat 2 ancaman validitas eksperimen yang terdiri atas validitas internal serta validitas eksternal. Dalam penelitian ini validitas internal yang perlu dikontrol terdiri atas karakteristik subjek yang dikendalikan melalui penentuan sampel dengan cara mengacak kelas serta melalui pengunaan kelompok yang setara yaitu dengan teknik matching, ancaman instrumen pada penelitian ini dikendalikan dengan prosedur penelitian yang tepat dan instrumen yang digunakan harus diujicobakan terlebih dahulu. Instrumen yang digunakan adalah instrumen yang telah dijudges secara teoritik serta penggunaan instrumen yang sama pada kelompok eksperimen dan kelompok kontrol, ancaman sejarah pada penelitian ini dapat dikendalikan dengan cara guru yang memberikan perlakuan pada kelompok eksperimen dan kelompok kontrol memiliki kualifikasi jenjang pendidikan yang setara, materi yang diberikan sama dan penggunaan kurikulum sama, ancaman kematangan pada penelitian ini dapat dikendalikan dengan cara penggunaan waktu perlakuan secara tepat dan efisien yaitu 6 kali dikelompok eksperimen dan 6 kali dikelompok kontrol sehingga kompetensi pengetahuan IPA siswa dapat mengalami perubahan dan ancaman sikap subjek dalam penelitian ini dapat dikendalikan dengan cara mengupayakan siswa agar menganggap bahwa eksperimen tersebut adalah suatu hal yang rutin sehingga tidak perlu memberikan reaksi yang berlebihan dan tidak dibentuk kelas baru serta guru yang mengajar adalah guru kelasnya. Menurut Dantes (2014:3) menyatakan "validitas eksternal mengacu pada sejauhmana suatu hasil penelitian dapat digeneralisasikan atau validitas eksternal menyangkut tingkat (kualitas) kerefresentatifan hasil penelitian digeneralisasikan pada populasinya". Ancaman validitas eksternal yang perlu diperhatikan dalam penelitian ini yaitu, melakukan pemilihan anggota secara acak (random) dalam penentuan sampel yang mewakili populasi. Teknik sampling yang digunakan dalam penelitian ini adalah teknik sampel kelompok dengan cara pengundian pada populasi yang sudah dibentuk dalam kelas-kelas, maka kemungkinan setiap kelas dalam populasi memiliki peluang untuk dijadikan sampel penelitian. Hasilnya dapat digeneralisasikan pada populasi yaitu siswa kelas V di SD Gugus IV Jendral Sudirman Denpasar Selatan.

Data yang dikumpulkan dalam penelitian ini adalah data kompetensi pengetahuan IPA siswa kelas V SD Negeri Gugus IV Jendral Sudirman Denpasar Selatan tahun ajaran 2016/2017. Metode yang digunakan dalam pengumpulan data penelitian ini adalah metode tes. Agung, (2014) menyatakan metode tes adalah cara memperoleh data berbentuk tugas yang diberikan dan harus dikerjakan oleh seseorang atau kelompok yang di tes Instrumen penelitian yang digunakan adalah tes. Menurut Suharsimi (2013:67) "Tes adalah alat atau prosedur yang digunakan untuk mengetahui atau mengukur sesuatu dalam suasana, dengan cara dan aturan-aturan yang sudah ditentukan”. Tes yang diberikan kepada siswa berupa tes esai. Tes esai yang digunakan dalam penelitian ini disesuaikan dengan indikator yang terdapat dalam tema.

Untuk menentukan layak tidaknya suatu instrumen maka perlu divalidasi.. Penggunaan tes sebagai instrumen dalam mendapatkan data yang akurat perlu disusun secara valid. Suatu tes dapat disebut valid jika tes 
tersebut benar - benar mampu mengukur apa yang seharusnya diukur. Hal ini sesuai dengan pendapat Suharsimi (2013:79) "Agar dapat diperoleh data yang valid, instrumen atau alat ukur mengevaluasinya harus valid". Uji validitas yang digunakan dalam penelitian ini yaitu validitas isi. Langkah--langkah yang ditempuh dalam memenuhi validitas isi adalah membuat tabel kisi-kisi soal serta penilaian instrumen yang dilakukan oleh dua orang pakar.

Setelah data dikumpulkan, selanjutnya data tersebut dianalisis. Data yang dianalisis pada kedua kelompok adalah data kompetensi pengetahuan IPA siswa. Analisis data yang digunakan adalah analisis statistik. Metode analisis data statistik berarti analisis data yang dilakukan menurut dasar-dasar statistik. Dalam penelitian ini dilakukan dua analisis yaitu analisis statistik deskriptif dan analisis statistik inferensial. Statistik deskriptif adalah statistik yang berfungsi untuk mendiskripsikan atau memberi gambaran terhadap obyek yang diteliti melalui data sampel atau populasi sebagaimana adanya, tanpa melakukan analisis dan membuat kesimpulan yang berlaku untuk umum (Sugiyono, 2016:29). Pada statistik deskriptif ini, dikemukakan cara-cara penyajian data seperti menghitung mean, standar deviasi dan varians. Mean atau rata-rata hitung adalah angka yang diperoleh dengan membagi jumlah nilai-nilai dengan jumlah subjek (Setyosari, 2015:251). Setelah mendapatkan mean dilakukan penghitungan standar deviasi dan varians. Standar deviasi (s) adalah suatu ukuran persebaran atau dispersi skor - skor. Varians adalah suatu angka yang menunjukkan ukuran variabilitas yang dihitung dengan jalan mengkuadratkan standar deviasi (Setyosari, 2015:258)

Statistik inferensial adalah suatu cara pengolahan data yang dilakukan dengan cara merapkan rumusrumus statistik inferensial untuk menguji suatu hipotesis penelitian yang diajukan dan menarik kesimpulan berdasarkan hasil pengujian terhadap hipotesis (Agung, 2014). Teknik analisis data yang dilakukan untuk uji hipotesis dengan menggunakan uji-t, terlebih dahulu dilakukan uji prasyarat analisis yang terdiri dari uji normalitas sebaran data dan uji homogenitas varians.

Sebelum dilakukan uji hipotesis terlebih dahulu dilakukan uji prasyarat analisis yang terdiri dari uji normalitas sebaran data dan uji homogenitas. Uji normalitas dimaksudkan untuk mengetahui apakah sebaran data skor kompetensi pengetahuan IPA siswa masing-masing kelompok berdistribusi normal atau tidak sehingga dapat menentukan teknik analisis datanya. Uji Normalitas sebaran data dalam penelitian ini menggunakan Chi-kuadrat. Kriteria pengujian adalah jika koefisien $\chi_{\text {hitung }}^{2} \leq$ koefisien $\chi_{\text {tabel }}^{2}$, maka ho diterima (gagal ditolak) yang berarti data berdistribusi normal. Uji Homogenitas dilakukan untuk menunjukkan bahwa perbedaan yang terjadi pada uji hipotesis benar-benar terjadi akibat adanya perbedaan varians antar kelompok, bukan sebagai akibat perbedaan dalam kelompok. Uji homogenitas dapat dilakukan apabila kelompok data tersebut berdistribusi normal. Uji homogenitas varians dilakukan dengan uji F. Kriteria pengujian, jika koefisien $F_{\text {hitung }} \leq$ koefisien $F_{\text {tabel }}$ maka sampel homogen. Analisis data dalam penelitian ini menggunakan uji beda mean (uji t) dengan rumus separated. Rumus uji-t dengan rumus separated digunakan karena jumlah anggota sampel sama $\mathrm{n} 1=\mathrm{n} 2$ dan varians homogen. Kriterianya jika koefisien $t_{\text {hitung }} \leq$ koefisien $t_{\text {tabel }}$, maka Ho diterima dan Ha ditolak, dan jika koefisien $t_{\text {hitung }}>$ koefisien $\mathrm{t}_{\text {tabel }}$ maka Ho ditolak dan Ha diterima. Pada taraf signifikansi 5\% $(\alpha=0,05)$ dan dk $=\mathrm{n} 1+\mathrm{n} 2-2$.

\section{Hasil Dan Pembahasan}

Berdasarkan hasil analisis data kompetensi pengetahuan IPA pada kelompok eksperimen, diketahui bahwa rerata kompetensi pengetahuan IPA kelompok eksperimen $\bar{X}=78,05$ sedangkan rerata kompetensi pengetahuan IPA kelompok kontrol $\bar{X}=71,51$.

Hasil uji normalitas data kompetensi pengetahuan IPA kelompok eksperimen dengan model pembelajaran open ended berbasis keterampilan menjelaskan $\mathrm{X}^{2}{ }_{\text {hitung }}=9,27<\mathrm{X}_{\text {tabel }}=11,07$, maka data kompetensi pengetahuan IPA kelompok eksperimen adalah berdistribusi normal. Sementara hasil uji normalitas data kompetensi pengetahuan IPA siswa pada kelompok kontrol $\mathrm{X}^{2}{ }_{\text {hitung }}=0,30<\mathrm{X}_{\text {tabel }}=11,07$, maka data kompetensi pengetahuan IPA siswa untuk kelompok kontrol adalah berdistribusi normal.

Hasil uji homogenitas varians data kompetensi pengetahuan IPA yaitu $F_{\text {hitung }}=1,51$. Pada taraf signifikansi $5 \%$ dengan $\mathrm{dk}$ pembilang $=38$ dan $\mathrm{dk}$ penyebut $=38$ maka diperoleh $\mathrm{F}_{\text {tabel }}$ adalah 1,71. Karena $\mathrm{F}_{\text {hitung }}=$ $1,51<\mathrm{F}_{\text {tabel }}=1,71$, maka kompetensi pengetahuan IPA siswa pada kelompok eksperimen serta kelompok kontrol mempunyai varians yang homogen. Berdasarkan hasil uji normalitas dan homogenitas dapat diketahui bahwa data yang diperoleh dari kelompok eksperimen dan kelompok kontrol berdistribusi normal dan memiliki varians yang homogen. Karena data yang diperoleh telah memenuhi semua prasyarat, uji hipotesis dilakukan dengan menggunakan analisis uji-t.

Adapun kriteria pengujiannya adalah apabila koefisien $\mathrm{t}_{\text {hitung }} \leq$ koefisien $\mathrm{t}_{\text {tabel }}$, maka Ho diterima dan Ha ditolak. Sebaliknya apabila koefisien $t_{\text {hitung }}>$ koefisien $t_{\text {tabel }}$, maka Ho ditolak dan Ha diterima. Dengan $\mathrm{db}=\mathrm{n} 1+$ $\mathrm{n} 2-2$ dan taraf signifikansi 5\% $(\alpha=0,05)$ atau taraf kepercayaan 95\%. Hasil uji t dapat dilihat pada tabel 1 . 
Tabel 1. Tabel Hasil Analisis Uji-t Data Kompetensi Pengetahuan IPA

\begin{tabular}{lllllll}
\hline \multicolumn{1}{c}{ Sampel } & $\mathrm{N}$ & $\mathrm{Dk}$ & $\overline{\boldsymbol{X}}$ & $\mathrm{s}^{2}$ & $t_{\text {hitung }}$ & $t_{\text {tabel }}$ \\
\hline Kelompok eksperimen & 39 & & 78,05 & 82,83 & & \\
Kelompok Kontrol & 39 & 76 & 71,51 & 54,66 & 3,497 & 2,000 \\
\hline
\end{tabular}

Untuk mengetahui signifikansi hasil perhitungan uji hipotesis di atas, maka perlu dibandingkan dengan koefisien $t_{\text {tabel. }}$. koefisien $t_{\text {tabel }}$ dengan taraf signifikansi $5 \%$ dan $d k=76\left(n_{1}+n_{2}-2\right)=2,000$. Hasil analisis uji $t$ diperoleh $t_{\text {hitung }}=3,497$. Koefisien tersebut kemudian dibandingkan dengan koefisien $t_{\text {tabel }}$ dengan $\mathrm{dk}=39+39-2$ $=76$ dan taraf signifikansi 5\% diperoleh koefisien $t_{\text {tabel }}=2,000$, karena $t_{\text {hitung }}=3,497>\mathrm{t}_{\text {tabel }}(\alpha=0,05,76)=2,000$ maka $\mathrm{H}_{\mathrm{o}}$ yang menyatakan tidak terdapat perbedaan yang signifikan kompetensi pengetahuan IPA antara kelompok eksperimen dengan kelompok kontrol pada kelas V SD Gugus IV Jendral Sudirman Denpasar Selatan tahun ajaran 2016/2017 ditolak atau $\mathrm{H}_{\mathrm{a}}$ diterima.

Dari perolehan kompetensi pengetahuan pada kedua kelompok dapat diketahui bahwa kedua kelompok yang awalnya memiliki kemampuan setara, lalu setelah diberikan treatment yang berbeda perolehan kompetensi pengetahuan mengalami perbedaan. Kompetensi pengetahuan siswa pada kelompok eksperimen lebih baik apabila dibandingkan dengan kompetensi pengetahuan siswa pada kelompok kontrol. Hal ini disebabkan oleh pembelajaran yang diterapkan pada kelompok eksperimen memiliki banyak keunggulan.

Perbedaan yang signifikan kompetensi pengetahuan IPA antara kelompok eksperimen dengan kelompok kontrol karena perbedaan pemberian treatment yang diberikan saat pembelajaran IPA. Kelompok eksperimen diberikan pembelajaran melalui model open ended berbasis keterampilan menjelaskan memiliki nilai rata-rata yang lebih tinggi dibandingkan dengan kelompok kontrol yang dibelajarkan dengan pembelajaran sebagaimana di sekolah dasar.

Hal ini disebabkan karena model pembelajaran open ended berbasis keterampilan menjelaskan dapat meningkatkan rasa ingin tahu siswa dan termotivasi dalam pembelajaran karena siswa dalam pembelajaran diberi kesempatan untuk memecahkan masalah yang ditemukan dikehidupan nyata dengan berbasis keterampilan menjelaskan yang diberikan guru dapat membantu proses pemecahan masalah tersebut. Hal tersebut membuat pembelajaran IPA lebih dipahami oleh siswa sehingga berdampak positif terhadap kompetensi pengetahuan IPA.

Model pembelajaran open ended menonjolkan pemberian permasalahan terbuka yang memerlukan kemampuan pemecahan masalah yang beragam, sedangkan keterampilan menjelaskan bermanfaat untuk semua siswa dalam menemukan solusi untuk pemecahan masalah yang diberikan guru. Model pembelajaran open ended memiliki keunggulan yang diungkapkan oleh (Shoimin, 2014:112) yaitu (1) siswa berpartisipasi lebih aktif dalam pembelajaran dan sering mengekspresikan idenya; (2) siswa memiliki kesempatan lebih banyak dalam memanfaatkan pengetahuan dan keterampilan secara komprehensif; (3) siswa dengan kemampuan rendah dapat merespons permasalahan dengan cara mereka sendiri; (4) siswa secara intrinsik termotivasi untuk memberikan bukti atau penjelasan; serta (5) siswa memiliki pengalaman banyak untuk menemukan sesuatu dalam menjawab permasalahan. Penerapan keterampilan menjelaskan akan membantu pemahaman siswa terhadap masalah yang didapatkan serta membantu siswa dalam menemukan solusi untuk memecahkan masalah yang didapatkannya. Hal ini menyebabkan siswa menjadi cepat memahami materi karena selain siswa mencari sendiri pengetahuannya siswa juga mendapatkan pengetahuan dari penjelasan yang diberikan oleh guru.

Berbeda dengan pembelajaran yang dilaksanakan selama pembelajaran IPA di kelompok kontrol. Kegiatan pembelajaran dilakukan dengan cara menyampaikan sejumlah materi kepada siswa yang diselingi dengan sedikit tanya jawab kemudian diikuti dengan pemberian tugas secara individu. Dengan pembelajaran seperti ini, siswa tidak mempunyai kesempatan untuk mengembangkan kemampuan berpikir, kesempatan untuk bekerjasama dengan teman sebaya, serta memecahkan masalah yang ditemui. Pembelajaran seperti ini, membuat siswa merasa bosan dan jenuh sehingga sulit untuk memahami materi pelajaran.

Penelitian ini diperkuat oleh penelitian yang dilakukan oleh Pariasa (2015) dari hasil uji hipotesis diperoleh hasil koefisien $t_{\text {hitung }}=28,82$, pada taraf signifikansi $5 \%$ dan $\mathrm{db}=47$ koefisien $\mathrm{t}_{\text {tabel }}=2,02$. Karena $\mathrm{t}_{\text {hitung }}=28,82>$ $\mathrm{t}_{\text {tabel }}=2,02$ maka $\mathrm{H}_{\mathrm{o}}$ ditolak dan $\mathrm{H}_{\mathrm{a}}$ diterima. Hal ini menunjukkan bahwa terdapat perbedaan yang signifikan terhadap hasil belajar matematika antara kelompok siswa yang mengikuti pembelajaran dengan pendekatan masalah terbuka (open-ended) dengan kelompok siswa yang mengikuti pembelajaran dengan pendekatan konvensional siswa kelas V SD gugus VII Kecamatan Tejakula. Rerata hasil belajar matematika siswa kelompok eskperimen $\bar{X}=41,7$ $>\bar{X}=32,05$ rerata hasil belajar matematika siswa kelompok kontrol. Sehingga dapat disimpulkan bahwa pendekatan masalah tebuka (open ended) berpengaruh terhadap hasil belajar matematika pada siswa kelas V SD Gugus VII Kecamatan Tejakula, Kabupaten Buleleng Tahun Pelajaran 2013/2014. 


\section{Simpulan Dan Saran}

Berdasarkan hasil pembahasan dan hasil analisis dapat disimpulkan bahwa model pembelajaran open ended berbasis keterampilan menjelaskan berpengaruh terhadap kompetensi pengetahuan IPA pada siswa kelas V SD Gugus IV Jendral Sudirman Denpasar Selatan Tahun Ajaran 2016/2017. Hal ini dibuktikan dengan hasil analisis uji-t dengan diperoleh $\mathrm{t}_{\text {hitung }}=3,479>\mathrm{t}_{\text {tabel }(a=0,05,76)}=2,000$, serta rerata kompetensi pengetahuan IPA kelompok eksperimen $\bar{X}=78,05, \bar{X}=71,51$ rerata kompetensi pengetahuan IPA kelompok kontrol.

Berdasarkan hasil penelitian ini, maka dapat diajukan beberapa saran guna peningkatan kualitas pembelajaran yaitu Kepada guru diharapkan agar mencobakan menerapkan model pembelajaran open ended berbasis keterampilan menjelaskan secara lebih lanjut untuk lebih meningkatkan kerjasama antara siswa dengan guru, siswa dengan siswa sehingga dapat meningkatkan kualitas pembelajaran sesuai dengan harapan.

Kepada kepala sekolah diharapkan agar model pembelajaran open ended berbasis keterampilan menjelaskan dapat dijadikan alternatif perbaikan kualitas pembelajaran dan mencapai tujuan pembelajaran yang diharapkan.

Kepada peneliti lain yang berminat untuk melanjutkan penelitian ini agar mengembangkan masalahmasalah yang belum terjangkau dalam penelitian ini sehingga menjadi penelitian yang memiliki kajian lebih luas dari penelitian ini.

\section{Daftar Pustaka}

Agung, A. A. Gede. 2014. Metodelogi Penelitian Pendidikan. Singaraja: Undiksha Arikunto, Suharsimi. 2012. Dasar-dasar Evaluasi Pendidikan. Jakarta : Bumi Aksara

Ariani, I M Desi. 2014. Pengaruh Implementasi Open-Ended Problem Dalam Pembelajaran Matematika Terhadap Kemampuan Pemecahan Masalah Dengan Pengendalian Kemampuan Penalaran Abstrak. e-Journal Program Pascasarjana Universitas Pendidikan Ganesha, Volume 4, Nomor 1 Tersedia Pada http://pasca.undiksha.ac.id/e-journal/index.php/jurnal_ep/article/view/ (diakses pada tanggal 26 Desember 2016).

Dantes, Nyoman. 2014. Analisis Dan Desain Eksperimen. Singaraja: Program Pasca Sarjana Undiksha

Darmadi, Hamid. 2014. Metode Penelitian Pendidikan dan Sosial. Bandung: Alfabeta

Kosasih, E. 2014. Strategi Belajar dan Pembelajaran Implementasi Kurikulum 2013. Bandung: Yrama Widya.

Martunis. 2014. Pembelajaran Open Ended Pada Luas Segitiga Siswa SMA Negeri 2 Indrajaya. Jurnal Sains Riset, Volume 1 Nomor 1. Tersedia pada http://www.academia.edu/6049528 (diakses tanggal 26 Desember 2016)

Maryam, Isnaeni. 2014. Pengaruh Pembelajaran Open Ended dan Konsstruktivis Terhadap Prestasi Belajar Matematika Ditinjau Dari Motivasi Belajar Siswa. Surya Edukasi, Volume 1, Nomor 1. Tersedia pada http://ejurnal.umpwr.ac.id/index.php/surya/articele/download/3180/2990 (diakses tanggal 26 Desember 2016)

Pariasa, I Komang dkk. 2015. Pengaruh Pendekatan Masalah Terbuka (Open-Ended) Terhadap Hasil Belajar Matematika Siswa Kelas V Sd Gugus Vii Kec. Tejakula, Tahun Pelajaran 2013/2014. e-Journal PGSD Universitas Pendidikan Ganesha, Volume 3, Nomor 1. Tersedia pada http://ejournal.undiksha.ac.id/index.php/JJPGSD/article/view/4720/3589 (diakses tanggal 26 Desember 2016).

Rahmawati, ES Yeni. 2014. Keefektifan Pendekatan Open-Ended Dan Ctl Ditinjau Dari Hasil Belajar Kognitif Dan Afektif. Jurnal Riset Pendidikan Matematika, Volume 1, Nomor 1. Tersedia pada http://download.portalgaruda.org/article.php?article=105343\&val=1342 (diakses pada tanggal 26 Desember 2016).

Sugiyono. 2016. Statistikan untuk Penelitian. Jakarta: Alfabeta.

Setyosari, Punaji. 2015. Metode Penelitian Pendidikan dan Pengembangan. Jakarta: Kencana

Shoimin, Aris. 2014. 68 Model Pembelajaran Inovatif dalam Kurikulum 2013. Yogyakarta: AR RUZZ MEDIA

Yanuar. A. 2015. Rahasia Jadi Guru Favorit-Inspiratif. Yogyakarta: DIVA Press 